\author{
dr Ewelina RABIEJ \\ Katedra Finansów, Wydział Ekonomii, Uniwersytet Rzeszowski \\ e-mail: erabiej@ur.edu.pl \\ ORCID: 0000-0003-0420-5217
}

DOI: $10.15290 /$ oes.2018.03.93.13

\title{
JEDNOSTKA SAMORZĄDU TERYTORIALNEGO JAKO PODMIOT TWORZĄCY SPZOZ - ANALIZA WYBRANYCH ASPEKTÓW PRAWNYCH I FINANSOWYCH
}

\begin{abstract}
Streszczenie
Celem artykułu jest analiza i ocena roli JST w systemie ochrony zdrowia. Autorka stawia hipotezę zakładająca, że sprawowanie przez JST funkcji podmiotu tworzącego SPZOZ stanowi zagrożenie dla stabilności finansów samorządowych. W opracowaniu dokonano analizy zadań i wydatków JST w zakresie ochrony zdrowia oraz przedstawiono uprawnienia i obowiązi JST jako podmiotów tworzących SPZOZ. Syntetycznie omówiono sytuację finansową SPZOZ i jej potencjalne skutki dla podmiotów tworzących, w kontekście realizacji zadań publicznych wynikających z konstytucyjnej odpowiedzialności państwa za zapewnienie obywatelom równego dostępu do świadczeń zdrowotnych. W artykule zastosowano metodę badań literaturowych, analizę aktów prawnych i dedukcję. Badania objęły lata 2014-2016.
\end{abstract}

Słowa kluczowe: finanse publiczne, samorząd terytorialny, samodzielny publiczny zakład opieki zdrowotnej, system ochrony zdrowia

\section{A LOCAL GOVERNMENT UNIT AS A FOUNDING ENTITY AN INDEPENDENT PUBLIC HEALTH CARE PROVIDER - ANALYSIS OF SELECTED LEGAL AND FINANCIAL ASPECTS}

\section{Summary}

This article analyses issues related to the role of local government units (JST) in the healthcare system. The author makes the hypothesis assuming that performing the function of the founding entity of the independent public health care provider (SPZOZ) by the JST is a threat to the stability of local government finances. The study analyses the tasks and expenses of the JST in terms of healthcare and presents the rights and obligations of the JST as the founding entities of SPZOZ. The final section focuses on the financial condition of SPZOZ and the impact on public finance stability as well as the equal access to health services. In the article, the following research methods were applied: the analysis of the literature, the analysis of legal acts, deduction. The study covered the years 2014-2016.

Keywords: public finance, local government, independent public health care provider, healthcare system

JEL classification: H51, H75, I18 


\section{Wstęp}

System zdrowotny w Polsce ma bardzo złożoną strukturę, której częścią są jednostki samorządu terytorialnego (JST) - gminy, powiaty, samorządy wojewódzkie. Uczestniczą one zarówno w organizacji, jak $\mathrm{i}$ w finansowaniu świadczeń zdrowotnych. W 1999 r. JST, poza licznymi zadaniami nałożonymi przez zmieniające się regulacje prawne, przejęły uprawnienia organów administracji rządowej, stając się podmiotami tworzącymi ${ }^{1}$ samodzielnych publicznych zakładów opieki zdrowotnej SPZOZ [Dercz, Izdebski, 2001, s. 121].

Jak wynika z porównań międzynarodowych, rola samorządu terytorialnego w systemie ochrony zdrowia jest zróżnicowana i zależna od przyjętego modelu ochrony zdrowia oraz możliwości prawnych i finansowych [McIntyre, Kutzin, 2016, s. 7; Włodarczyk, Poździoch, 2001; Karski, 2012]. Jak piszą K. Walshe i J. Smith, w wielu państwach historia systemów opieki zdrowotnej przeplata się z rozwojem struktur społecznych [Walshe, Smith, 2011, s. 24]. Cechą charakterystyczną większości systemów ochrony zdrowia w krajach Unii Europejskiej jest decentralizacja i wzmocnienie pozycji samorządów [Dercz, 2005, s. 13]. S. Golinowska zwraca uwagę na kwestię podatności systemów zdrowotnych na wpływy różnych grup interesów, w tym polityczne. Systemy zdecentralizowane, samorządowe mogą budzić większe zaufanie niz scentralizowane. Z drugiej strony w krajach o niskich dochodach zauważalna jest tendencja centralizacji zarządzania w odpowiedzi na ułomności systemów zarządzanych regionalnie lub lokalnie [Golinowska, 2015, s. 232].

Celem opracowania jest analiza i ocena roli JST w systemie ochrony zdrowia w Polsce. Autorka stawia hipotezę zakładająca, że sprawowanie przez JST funkcji podmiotu tworzącego SPZOZ stanowi zagrożenie dla stabilności finansów samorządowych.

Artykuł przygotowano na bazie badań literaturowych, analizy aktów prawnych regulujących funkcjonowanie systemu ochrony zdrowia w Polsce, sprawozdań z wykonania budżetu państwa za lata 2014-2016 i in. Wykorzystano dane statystyczne dostępne w Rejestrze Podmiotów Wykonujących Działalność Leczniczą oraz w bazach GUS, według ostatnich dostępnych aktualizacji.

\section{Finansowanie ochrony zdrowia przez JST}

Systemy ochrony zdrowia na świecie ulegają ciagłym przeobrażeniom, a cechą charakterystyczną reform ostatnich kilkudziesięciu lat jest zmiana poziomu i struktury źródeł finansowania świadczeń zdrowotnych [Getzen, 2000, s. 26]. Według J. Sucheckiej, kluczowa kwestia w procesie kształtowania systemu ochrony zdrowia jest przyjęcie takich sposobów finansowania ochrony zdrowia, aby zachowane zosta-

1 Podmiot tworzący - podmiot albo organ, który utworzył podmiot leczniczy w formie samodzielnego publicznego zakładu opieki zdrowotnej, jednostki budżetowej albo jednostki wojskowej [Ustawa 2011, art. 2, ust. 1, pkt 6]. 
ły reguły polityki gospodarczej, a jednocześnie aby były przestrzegane reguły polityki zdrowotnej [Suchecka, 2015, s. 13].

W Polsce przełomowym momentem była reforma systemu ochrony zdrowia z 1999 r., skutkująca przejściem z modelu Siemaszki do modelu ubezpieczeniowego [Karski, 2012, s. 39; Dercz, Izdebski, 2001, s. 131]. Nastapiła decentralizacja decyzyjności i finansowania [MZiOS, 1998, s. 6]. Zapewnienie mieszkańcom lokalnej społeczności równego dostępu do świadczeń opieki zdrowotnej stało się podstawowym zadaniem władz samorządowych $\mathrm{w}$ zakresie ochrony zdrowia. Zgodnie $\mathrm{z}$ art. 68. Konstytucji Rzeczpospolitej Polskiej, każdy ma prawo do ochrony zdrowia, a wladze publiczne maja obowiazek rapewnić obywatelom, niezależnie od ich sytuacii materialnej, równy dostep do świadczeń opieki żdrowotnej finansowanej ze środkón publicznych [Konstytucja ...]. Zadania władz publicznych w zakresie zapewnienia równego dostępu do świadczeń opieki zdrowotnej objęły:

- tworzenie warunków funkcjonowania systemu ochrony zdrowia;

- analizę i ocenę potrzeb zdrowotnych oraz czynników powodujących ich zmiany;

- promocję zdrowia i profilaktykę;

- finansowanie świadczeń opieki zdrowotnej w trybie i na zasadach określonych ustawa.

Samorząd terytorialny wykonuje zadania publiczne nie zastrzeżone przez Konstytucję lub ustawy dla organów innych władz publicznych. JST mają przede wszystkim obowiazzek realizacji programów polityki zdrowotnej, wynikających z rozpoznanych potrzeb zdrowotnych i stanu zdrowia mieszkańców. W obszarze działania gminy leży też inicjowanie i udział w wytyczaniu kierunków przedsięwzięć lokalnych zmierzających do zaznajamiania mieszkańców z czynnikami szkodliwymi dla zdrowia oraz ich skutkami. Do zadań powiatu należy inicjowanie, wspomaganie i monitorowanie działań lokalnej wspólnoty samorządowej w zakresie promocji zdrowia i edukacji zdrowotnej oraz pobudzanie działań na rzecz indywidualnej i zbiorowej odpowiedzialności za zdrowie i na rzecz ochrony zdrowia. Na poziomie województwa kluczową kwestią jest promowanie rozwiązań w zakresie wzrostu efektywności, w tym restrukturyzacji w ochronie zdrowia [Ustawa..., 2018, s. 123-139].

W 2016 r. wydatki JST na ochronę zdrowia wyniosły 3.320,5 mln zł (łącznie ze środkami otrzymanymi przez JST z budżetu państwa), tj. 86,4 zł per capita (z dużym zróżnicowaniem regionalnym). Wydatki na ochronę zdrowia stanowiły 1,6\% ogółu wydatków samorządów terytorialnych. W budżetach gmin dominowały wydatki na przeciwdziałanie alkoholizmowi $-70,1 \%$ i na szpitale ogólne $-6,4 \%$. Miasta na prawach powiatu wydatkowały środki finansowe przede wszystkim na przeciwdziałanie alkoholizmowi - $27,3 \%$, szpitale $-26,5 \%$ oraz na składki na ubezpieczenia zdrowotne i świadczenia dla osób nie objętych obowiązkiem ubezpieczenia zdrowotnego - 23,1\%. Wydatki powiatów przeznaczone były głównie na składki na ubezpieczenia zdrowotne oraz świadczenia dla osób nie objętych obowiązkiem ubezpieczenia zdrowotnego $-69 \%$ oraz na szpitale $-22 \%$. W budżetach województw dominowały wydatki na szpitale - 58,5\%, medycynę pracy - 10,9\% i lecznictwo psychiatryczne $-5,4 \%$ [GUS, 2017, s. 167]. 
Analiza wydatków samorządowych na ochronę zdrowia w latach 2014-2016 wskazuje generalnie na tendencje malejące. Jedynie wydatki gmin wzrosły, jednak nie był to znaczny wzrost: z poziomu 561,3 $\mathrm{mln}$ zł w $2014 \mathrm{r}$. do 586,4 $\mathrm{mln}$ zł, tj. o 4,4\%. Wydatki powiatów spadły o $19 \%$, do $1.036,1 \mathrm{mln}$ zł, wydatki miast na prawach powiatu spadły o $9 \%$, do $965,5 \mathrm{mln}$ zł, a wydatki samorządów wojewódzkich - o 5,5\%, do 732,5 mln zł. Największe wydatki w ujęciu globalnym zrealizowano więc $\mathrm{w}$ powiatach i w miastach na prawach powiatu (tabela 1).

Wydatki majątkowe JST na ochronę zdrowia w analizowanym okresie rosły: w gminach o $9 \%$ do poziomu $89,7 \mathrm{mln}$ zł (15\% wydatków ogółem na ochronę zdrowia), w powiatach o $39 \%$, do $231,9 \mathrm{mln}$ zł (22\% wydatków ogółem na ochronę zdrowia), a na poziomie województw - o 5\%, do 525,5 mln zł (72\% wydatków ogółem na ochronę zdrowia). Jedynie w miastach na prawach powiatu wydatki majątkowe spadły: o $15 \%$, do 270,2 mln zł (28\% wydatków ogółem na ochronę zdrowia). Najwyższe wydatki majątkowe realizowano więc na szczeblu województwa (tabela 1). Największy udział wydatków majątkowych w wydatkach ogółem na ochronę zdrowia od 80 do $90 \%$ - odnotowuje się w województwach: podlaskim, lubelskim, zachodniopomorskim, świętokrzyskim i podkarpackim [Wydatki JST..., 2017, s. 25].

TABELA 1

Wydatki jednostek samorządu terytorialnego w dziale „851 - Ochrona zdrowia” w latach 2014-2016

\begin{tabular}{|c|c|c|c|c|c|c|}
\hline \multirow[b]{2}{*}{ Wyszczególnienie } & \multicolumn{2}{|r|}{2014} & \multicolumn{2}{|r|}{2015} & \multicolumn{2}{|r|}{2016} \\
\hline & $\begin{array}{c}\text { w mln } \\
\text { zł }\end{array}$ & $\begin{array}{c}\text { udział } \\
\text { w budżecie } \\
\text { JST (w \%) }\end{array}$ & $\begin{array}{c}\text { w mln } \\
\text { zł }\end{array}$ & $\begin{array}{c}\text { udział } \\
\text { w budżecie } \\
\text { JST (w \%) }\end{array}$ & $\begin{array}{c}\text { w mln } \\
\text { zł }\end{array}$ & $\begin{array}{c}\text { udział } \\
\text { w budżecie } \\
\text { JST (w \%) }\end{array}$ \\
\hline $\begin{array}{l}\text { Gminy } \\
\text { ogótem: } \\
\text { majatkowe: }\end{array}$ & $\begin{array}{c}561,3 \\
82,2\end{array}$ & $\begin{array}{l}0,70 \\
0,10\end{array}$ & $\begin{array}{c}553,0 \\
65,4\end{array}$ & $\begin{array}{l}0,60 \\
0,08\end{array}$ & $\begin{array}{c}586,4 \\
89,7\end{array}$ & $\begin{array}{l}0,60 \\
0,09\end{array}$ \\
\hline $\begin{array}{l}\text { Powiaty } \\
\text { ogótem: } \\
\text { majatkowe: }\end{array}$ & $\begin{array}{c}1274,0 \\
166,5\end{array}$ & $\begin{array}{l}5,40 \\
0,70\end{array}$ & $\begin{array}{c}1183,7 \\
215,9\end{array}$ & $\begin{array}{l}5,00 \\
0,92\end{array}$ & $\begin{array}{c}1036,1 \\
231,9\end{array}$ & $\begin{array}{l}4,40 \\
0,99\end{array}$ \\
\hline $\begin{array}{l}\text { Miasta na prawach } \\
\text { powiatu } \\
\text { ogótem: } \\
\text { majatkowve: }\end{array}$ & $\begin{array}{c}1065,2 \\
318,3\end{array}$ & $\begin{array}{l}1,50 \\
0,46\end{array}$ & $\mid \begin{array}{c}1063,2 \\
349,9\end{array}$ & $\begin{array}{l}1,50 \\
0,50\end{array}$ & $\begin{array}{l}965,5 \\
270,2\end{array}$ & $\begin{array}{l}1,30 \\
0,38\end{array}$ \\
\hline $\begin{array}{l}\text { Samorządy } \\
\text { wojewódzkie } \\
\text { ogótem: } \\
\text { majatkowe: }\end{array}$ & $\begin{array}{l}774,7 \\
500,9\end{array}$ & $\begin{array}{l}4,20 \\
2,75\end{array}$ & $\begin{array}{c}1106,7 \\
827,2\end{array}$ & $\begin{array}{l}6,40 \\
4,81\end{array}$ & $\begin{array}{l}732,5 \\
525,5\end{array}$ & $\begin{array}{l}5,80 \\
4,16\end{array}$ \\
\hline
\end{tabular}

Źródło: opracowanie własne na podstawie sprawozdań z wykonania budżetu państwa za lata 2014-2016. 


\section{Uprawnienia właścicielskie JST wobec SPZOZ}

SPZOZ jest podstawowa forma organizacyjno-prawna publicznego podmiotu leczniczego ${ }^{2}$. Na dzień 21 lutego 2018 r. zarejestrowane były ogółem 1062 samorządowe SPZOZ, w tym 596 gminnych, 229 powiatowych i 237 wojewódzkich [RPWDL].

SPZOZ ma status jednostki sektora finansów publicznych, która prowadzi gospodarkę finansową na podstawie ustawy z dnia 15 kwietnia 2011 r. o działalności leczniczej [Ustawa 2011], zgodnie z zasadą samodzielności finansowej - pokrywa z posiadanych środków i uzyskiwanych przychodów koszty działalności i reguluje zobowiązania. SPZOZ może uzyskiwać środki finansowe z odpłatnej działalności leczniczej, z wydzielonej działalności innej niż lecznicza (jeżeli statut przewiduje prowadzenie takiej działalności), z odsetek od lokat, darowizn, zapisów, spadków oraz ofiarności publicznej, także pochodzenia zagranicznego.

Uprawnienia JST jako podmiotów tworzących SPZOZ określa ustawa z dnia 15 kwietnia 2011 r. o działalności leczniczej [Ustawa 2011]. Wymienia się tu możliwość tworzenia, przekształcenia i likwidacji SPZOZ, nadawanie statutu, nawiazywanie z kierownikiem SPZOZ stosunku pracy, powoływanie i odwoływanie rady społecznej. JST sprawuje również nadzór nad SPZOZ w zakresie realizacji zadań określonych w regulaminie organizacyjnym i statucie, dostępności i jakości udzielanych świadczeń zdrowotnych, prawidłowości gospodarowania mieniem oraz środkami publicznymi, a także gospodarki finansowej.

Uprawnienia majątkowo-finansowe JST względem SPZOZ dotyczą wyposażania w majątek, określania zasad gospodarowania majątkiem, wyrażania zgody na wnoszenie majątku SPZOZ do innych podmiotów, wyrażania zgody na zmianę wierzyciela SPZOZ, zatwierdzania rocznego sprawozdania finansowego, a także przekazywania środków finansowych $\mathrm{w}$ formie dotacji lub na podstawie umowy, na zasadach i na cele ściśle określone w ustawie. JST jako podmiot tworzący może przekazać SPZOZ środki finansowe na inwestycje w nieruchomości, zakup aparatury i sprzętu, kształcenie kadry medycznej, realizację zadań w zakresie programów zdrowotnych i promocji zdrowia. Uprawnienia właścicielskie JST w zakresie polityki inwestycyjnej w SPZOZ zostały w pewnym stopniu ograniczone w 2016 r. poprzez wprowadzenie systemu opiniowania celowości inwestycji w sektorze ochrony zdrowia (tzw. system IOWISZ). Podmiotem opiniującym celowość inwestycji dla JST jest wojewoda, który wydaje decyzję uwzględniając mapę potrzeb zdrowotnych, priorytety dla regionalnej polityki zdrowotnej, dane z rejestru podmiotów wykonujących działalność leczniczą oraz opinię dyrektora oddziału wojewódzkiego NFZ. Pozytywna opinia o celowości inwestycji jest warunkiem formalnym uzyskania dofinansowania projektu ze środków europejskich w okresie programowania 2014-2020, a także

2 Zgodnie z ustawa z dnia 15 kwietnia 2011 r. o działalności leczniczej [Ustawa 2011], JST mogą utworzyć i prowadzić podmiot leczniczy również w formie jednostki budżetowej lub spółki kapitałowej. 
wpływa na ocenę oferty SPZOZ w postępowaniach w sprawie zawarcia umów o udzielanie świadczeń opieki zdrowotnej z NFZ [Ustawa ..., 2018, s. 671].

W 2016 r. ustawa z dnia 30 czerwca 2016 r. o zmianie ustawy o działalności leczniczej oraz niektórych innych ustaw (Dz. U. 2016 poz. 960) poszerzyła uprawnienia JST w zakresie finansowania działalności bieżącej SPZOZ, umożliwiając im przekazywanie środków na tzw. gwarantowane świadczenia zdrowotne ${ }^{3}$. Decyzja o ich finansowaniu podejmowana jest na podstawie analizy regionalnych potrzeb zdrowotnych, priorytetów dla regionalnej polityki zdrowotnej oraz stanu dostępności do świadczeń opieki zdrowotnej4.

W celu wzmocnienia funkcji kontrolnej JST jako podmiotu tworzacego, ustawa z dnia 15 kwietnia 2011 r. o działalności leczniczej [Ustawa 2011] zobligowała kierownika SPZOZ do składania corocznego raportu o sytuacji ekonomicznofinansowej. Raport przygotowywany jest na podstawie sprawozdania finansowego za poprzedni rok obrotowy i przedkładany podmiotowi tworzacemu w terminie do dnia 31 maja. Jeżeli w sprawozdaniu finansowym wystapiła strata netto kierownik SPZOZ zobowiązany jest w terminie 3 miesięcy od upływu terminu do zatwierdzenia sprawozdania finansowego, do sporządzenia i przedłożenia do zatwierdzenia podmiotowi tworzącemu programu naprawczego. Ujemny wynik finansowy SPZOZ pokrywa samodzielnie $z$ funduszu zakładu. Jeżeli nie jest to możliwe, JST jako podmiot tworzacy zobowiązana jest do podjęcia działań określonych w ustawie z dnia 15 kwietnia 2011 r. o działalności leczniczej [Ustawa 2011], tj.:

- 9 miesięcy od upływu terminu zatwierdzenia sprawozdania finansowego SPZOZ powinna pokryć stratę netto za rok obrotowy zakładu w kwocie, jaka nie może być pokryta z funduszu zakładu, jednak nie wyższej niż suma straty netto i amortyzacji, lub

- 12 miesięcy od upływu terminu pokrycia straty netto - podjąć decyzję o likwidacji SPZOZ.

Decyzja o likwidacji SPZOZ wiąże się z koniecznością przejęcia jego zobowiązań przez podmiot tworzący. Oba rozwiązania - zarówno pokrycie straty netto jak i likwidacja SPZOZ - oznaczają więc dla JST obciążenie finansowe.

\section{Sytuacja finansowa SPZOZ i jej konsekwencje dla JST}

JST jako podmioty tworzace, ponoszą konsekwencje gospodarki finansowej SPZOZ, stąd straty i zadłużenie SPZOZ mogą zagrażać stabilności finansowej JST.

3 Świadczenia gwarantowane to świadczenia opieki zdrowotnej finansowane w całości lub współfinansowane ze środków publicznych na zasadach i w zakresie określonych w ustawie z dnia 27 sierpnia 2004 r. o świadczeniach opieki zdrowotnej finansowanych ze środków publicznych [Ustawa 2004].

4 Brak możliwości wspomagania finansowego bieżącej działalności SPZOZ był wcześniej szeroko krytykowany, por.: [Golinowska, 2008, s. 28]. 
Gospodarka finansowa JST regulowana jest ustawą z dnia 27 sierpnia 2009 r. o finansach publicznych [Ustawa 2009], określającą m.in. tzw. reguły fiskalne, które maja przeciwdziałać nadmiernemu zadłużaniu się JST. Pierwsza reguła odnosi się do zasady równoważenia budżetu w części bieżącej, zgodnie z którą organ stanowiący JST nie może uchwalić budżetu, w którym planowane wydatki bieżące są wyższe niż planowane dochody bieżące powiększone o nadwyżkę budżetową z lat ubiegłych i tzw. wolne środki (art. 242). Druga reguła fiskalna odnosi się do spełnienia relacji $z$ art. 243 ustawy, tj. zachowania przez każda JST indywidualnego wskaźnika obsługi zadłużenia na poziomie nie wyższym niż dopuszczalny. W 2016 r. reguły wydatkowej z art. 242 nie spełniło 16 JST - 13 gmin i 3 powiaty. Relacji z art. 243 nie spełniło 48 JST, tj. 1,7\% wszystkich JST, z tego: 33 gminy, 14 powiatów i 1 miasto na prawach powiatu. Budżety 2.245 JST zamknęły się nadwyżką na łączna kwotę 8.682.820 tys. zł, a 563 JST odnotowały deficyt na łączną kwotę 1.048 .448 tys. zł [KRRIO, 2017, s. 266; Sprawozdania..., 2017, s. 34].

Sytuacja finansowa podmiotów leczniczych podległych JST jest bardzo zróżnicowana. Jak wynika z danych Ministerstwa Zdrowia, rok 2016 zamknął się dla 1.072 samorządowych SPZOZ łączną stratą na poziomie 318,3 mln zł. Największe straty odnotowano w województwach: podkarpackim, śląskim i mazowieckim - odpowiednio - 116,7 mln zł; 83,7 mln zł; $68 \mathrm{mln}$ zł - łącznie 268,4 mln. Dodatni wynik finansowy zarejestrowano w województwach: pomorskim, lubuskim, łódzkim, małopolskim, podlaskim i kujawsko-pomorskim [CSIOZ, 2017, s. 91-126]. Największe straty generują SPZOZ dla których podmiotem tworzącym jest województwo. Są to najczęściej duże, wysokospecjalistyczne szpitale.

W 2016 r. zobowiązania samorządowych SPZOZ wyniosły 4,3 mld zł, co oznacza, że wzrosły jedynie nieznacznie w stosunku do 2015 r. - o 0,4\%. Zobowiazania wymagalne wynosiły w 2016 r. 1,1 mld zł, co oznacza minimalny spadek - o 0,9\%. Ich udział w zobowiązaniach ogółem kształtował się na poziomie $26 \%$. Zadłużenie SPZOZ zostało wykazane przez 261 JST: 16 województw samorządowych, 163 powiaty, 62 gminy oraz 20 miast na prawach powiatu. W najbardziej zadłużonych SPZOZ, tj. powiatowych i wojewódzkich, wzrost długu wyniósł odpowiednio 2,3\% oraz $3,5 \%$, w miastach na prawach powiatu zobowiązania spadły o $10,9 \%$ (tabela 2 ). W 7 województwach odnotowano wzrost wysokości zobowiązań wojewódzkich samorządowych SPZOZ. Największy kwotowo wzrost zobowiązań wystąił w województwie podkarpackim - o 47,7 mln zł, tj. o 17\% i lubelskim - o $46 \mathrm{mln}$ zł, tj. o 12,7\%. Największy kwotowy spadek zobowiązań odnotowano w województwie świętokrzyskim - o 21,6 mln zł, tj. o 28,7\% i wielkopolskim - o 17,1 mln zł, tj. o $6,7 \%$. W powiatach województwa opolskiego, lubuskiego, warmińsko-mazurskiego oraz podkarpackiego zobowiązania SPZOZ wzrosły w 2016 r. o ponad 10\%, odpowiednio: $42,8 \%, 22 \%, 15,9 \%, 10,8 \%$. Kwotowo największy wzrost zobowiązań wystapił w powiatowych SPZOZ w województwie podkarpackim - o 13,7 mln zl, lubuskim - o 12,1 mln zł i opolskim - o 10,1 mln zł. W 5 województwach zobowiązania powiatowych SPZOZ obniżyły się - największy spadek kwoty zobowiązań odnotowano w powiatowych SPZOZ województwa małopolskiego - o 12,1 $\mathrm{mln}$ zł, tj. o 12,7\%), dolnośląskiego - o 9,1 mln zł, tj. o 9,4\% oraz lubelskiego - o 6,3 mln 
zł, tj. o 3,9\%. Zadłużenie samorządowych SPZOZ rozłożone jest więc regionalnie bardzo nierównomiernie (KRRIO, 2017, s. 276-279).

TABELA 2

Zobowiązania samorządowych SPZOZ w 2015 i 2016 r. (w tys. zł)

\begin{tabular}{|c|c|c|}
\hline Wyszczególnienie & Zobowiązania ogółem & Zobowiązania wymagalne \\
\hline \multicolumn{3}{|l|}{ Gminy } \\
\hline 2015 & 16981 & 3694 \\
\hline 2016 & 20543 & 5029 \\
\hline \multicolumn{3}{|l|}{ M. st. Warszawa } \\
\hline 2015 & 49286 & 40582 \\
\hline 2016 & 57725 & 46626 \\
\hline \multicolumn{3}{|l|}{ Miasta na prawach powiatu } \\
\hline 2015 & 863330 & 172902 \\
\hline 2016 & 769402 & 164270 \\
\hline \multicolumn{3}{|l|}{ Powiaty } \\
\hline 2015 & 1334194 & 418939 \\
\hline 2016 & 1364849 & 371389 \\
\hline \multicolumn{3}{|l|}{ Województwa } \\
\hline 2015 & 1983491 & 487773 \\
\hline 2016 & 2053140 & 526573 \\
\hline \multicolumn{3}{|l|}{ RAZEM } \\
\hline 2015 & 4247282 & 1123890 \\
\hline 2016 & 4265660 & 1113887 \\
\hline
\end{tabular}

Źródło: opracowanie własne na podstawie [KRRIO, 2017, s. 276].

W 2016 r. relacja zobowiązań własnych JST do ich dochodów ukształtowała się na poziomie 32,3\%, a po uwzględnieniu zadłużenia SPZOZ wskaźnik wzrósł do $34,3 \%$, różnicując się na szczeblach samorządowych: od 23,5\% w gminach, $28,9 \%$ w powiatach, 46,8\% w miastach na prawach powiatu, aż do $65,3 \% \mathrm{w}$ województwach (tabela 3). Analizowana relacja jest również zróżnicowana regionalnie. Relacja sumy zobowiązań województw i nadzorowanych przez nie SPZOZ do dochodów województw kształtuje się od 31,3\% w województwie opolskim do 137,5\% w województwie lubelskim; natomiast relacja sumy zobowiązań powiatów i nadzorowanych przez nie SPZOZ do dochodów powiatów wynosi od 16,2\% w województwie podlaskim do 49,2\% w województwie lubuskim [KRRIO, 2017, s. 276]. 
TABELA 3

Zobowiązania ogółem jednostek samorządu terytorialnego i samodzielnych publicznych zakładów opieki zdrowotnej w 2016 r.

\begin{tabular}{|l|c|c|c|c|}
\hline Wyszczególnienie & $\begin{array}{c}\text { Zobowiązania } \\
\text { JST (w mln } \\
\text { zł) }\end{array}$ & $\begin{array}{c}\text { Zobowiązania } \\
\text { samorządowych } \\
\text { SPZOZ } \\
\text { (w mln zł) }\end{array}$ & $\begin{array}{c}\text { Relacja } \\
\text { zobowiązań } \\
\text { JST } \\
\text { do dochodów } \\
\text { JST (w \%) }\end{array}$ & $\begin{array}{c}\text { Relacja sumy } \\
\text { zobowiązań JST } \\
\text { i nadzorowanych } \\
\text { SPZOZ } \\
\text { do dochodów JST } \\
\text { (w \%) }\end{array}$ \\
\hline Gminy & 23863,5 & 20,5 & 23,4 & 23,5 \\
\hline Miasto st. Warszawa & 5677,2 & 57,7 & 38,6 & 39,0 \\
\hline $\begin{array}{l}\text { Miasta na prawach } \\
\text { powiatu }\end{array}$ & 27144,5 & 769,4 & 45,5 & 46,8 \\
\hline Powiaty & 5565,8 & 1364,8 & 23,2 & 28,9 \\
\hline Województwa & 6768,9 & 2053,1 & 50,1 & 65,3 \\
\hline RAZEM & 69019,9 & 4265,7 & 32,3 & 34,3 \\
\hline
\end{tabular}

Źródło: opracowanie własne na podstawie [KRRIO, 2017, s. 276].

Trudna sytuacja finansowa, generowanie strat i pogłębiające się zadłużenie są podstawa do rozważenia przez JST trzeciego wariantu działania (poza pokryciem strat lub likwidacją jednostki), tj. komercjalizacji SPZOZ. Zgodnie z ustawą z dnia 15 kwietnia 2011 r. o działalności leczniczej [Ustawa 2011], JST jako podmiot tworzący może podjąć decyzję o przekształceniu podlegającego mu SPZOZ-u w spółkę kapitałowa. Według H. Wolskiej i W. Goneta, mając na uwadze bezpieczeństwo finansów publicznych, prowadzenie podmiotu leczniczego w tej formie jest dla JST korzystniejsze, ponieważ w przypadku pogorszenia sytuacji finansowej spółki kapitałowej, JST nie odpowiada za jej zobowiązania. Z drugiej jednak strony, przyjmując jako kryterium oceny konstytucyjną odpowiedzialność państwa za ochronę zdrowia, SPZOZ jest formą bezpieczniejsza, ponieważ zgodnie z art. 6. ustawy z dnia 28 lutego 2003 r. Prawo upadłościowe [Ustawa 2003] nie można ogłosić upadłości SPZOZ, a więc utrata zdolności do wykonywania wymagalnych zobowiązań pieniężnych nie wpływa bezpośrednio na decyzję o zaprzestaniu działalności [Wolska, Gonet, 2017, s. 175-183].

Punktem wyjścia procesu komercjalizacji jest ustalenie wskaźnika zadłużenia, dalsze działania uzależnione są od jego wysokości. Wskaźnik zadłużenia SPZOZ jest relacją sumy zobowiązań długoterminowych i krótkoterminowych, pomniejszonych o inwestycje krótkoterminowe do sumy przychodów. Jeżeli wskaźnik wynosi powyżej 0,5, to JST, przed dniem przekształcenia, przejmuje zobowiązania SPZOZ o takiej wartości, aby wskaźnik zadłużenia wyniósł nie więcej niż 0,5. Jeżeli wskaźnik wynosi 0,5 lub mniej, to JST może, przed dniem przekształcenia, przejąć zobowiązania SPZOZ. Wydatki JST poniesione na spłatę przejętych zobowiązań SPZOZ przekształconych na zasadach określonych w ustawie z dnia 15 kwietnia 2011 r. o działalności leczniczej [Ustawa 2011] w spółki kapitałowe w latach 2014-2016 
wyniosły łącznie 79,2 mln zł, w tym najwięcej w powiatach i miastach na prawach powiatu - 59,6 mln zł, samorząd wojewódzki - 18,8 $\mathrm{mln}$ zł, gminy - 0,8 $\mathrm{mln}$ zł. W 2016 r. zaznaczyła się tendencja spadkowa wydatków poniesionych przez JST na spłatę tej grupy zobowiązań na wszystkich szczeblach samorządu [Sprawożdania ...].

\section{Podsumowanie}

Jak wynika z przeprowadzonej analizy, sprawowanie przez JST funkcji podmiotów tworzących SPZOZ jest jednym z najważniejszych aspektów uczestnictwa instytucji samorządowych $\mathrm{w}$ systemie zdrowotnym $\mathrm{w}$ Polsce. JST maja coraz szersze kompetencje w zakresie organizacji i finansowania ochrony zdrowia, co jednak niekoniecznie znajduje odzwierciedlenie w poziomie wydatków JST na ochronę zdrowia.

Nie można jednoznacznie pozytywnie zweryfikować postawionej hipotezy. Sprawowanie przez JST funkcji podmiotu tworzącego SPZOZ może stanowić zagrożenie dla stabilności finansów samorządowych, jeżeli zaistnieją określone warunki. Przepisy regulujące gospodarkę finansową SPZOZ same w sobie stanowią zagrożenie dla finansów JST, jednak, dopóki sytuacja finansowa SPZOZ nie ulegnie znacznemu pogorszeniu, to sprawowanie przez JST funkcji podmiotu tworzącego SPZOZ nie wiąże się ze szczególnym ryzykiem.

Jak wynika z przeprowadzonej analizy, sytuacja finansowa samorządowych SPZOZ jest bardzo zróżnicowana, zarówno uwzględniając kryterium szczebla JST jak i kryterium regionalne. W 2016 r. łączne straty sięgnęły 318,3 $\mathrm{mln}$ zł, a zobowiązania wyniosły 4,3 mld zl, co niestety oznacza stałą tendencję wzrostową. Zobowiązania wymagalne nieznacznie spadły, ale ich średni udział w zobowiązaniach ogółem to wciąż wysoki poziom 26\%. Najbardziej zadłużone są SPZOZ wojewódzkie i powiatowe - zadłużenie wykazane zostało przez wszystkie samorząqdy wojewódzkie i blisko połowę powiatów. Uwzględnienie zobowiązań SPZOZ we wskaźniku zobowiązań własnych JST do ich dochodów nie podnosi wprawdzie dramatycznie jego średniego poziomu, jednak znów zauważalne jest zróżnicowanie na szczeblach JST oraz regionalne: na poziomie województwa to wzrost o 15,2 punktu procentowego, a na poziomie powiatów - 5,7 punktu procentowego. Wskaźnik ten niesie ważne informacje, nie ma jednak charakteru ustawowego. Stabilność finansowa JST oceniana jest $\mathrm{w}$ kontekście spełnienia reguł fiskalnych określonych w ustawie, z których druga (art. 243) ma charakter całkowicie indywidualny. W związku z tym, konieczne są tu indywidualne analizy dla poszczególnych JST i podległych im SPZOZ, poszerzone dodatkowo o inne wskaźniki (m.in. poziom nadwyżki operacyjnej). Z uwagi na trudną sytuację finansową wojewódzkich i powiatowych SPZOZ, to właśnie dla tych szczebli samorządu takie analizy i diagnozy wydają się być konieczne, gdyż tu należy upatrywać potencjalnie największego zagrożenia dla finansów publicznych.

Sektor ochrony zdrowia jest specyficznym systemem, a niespójność konstrukcji prawnej SPZOZ nie ułatwia realizacji funkcji zarządczych. Jak piszą R. Jacobs, P.C. 
Smith i A. Street, wiele decyzji w ochronie zdrowia ma charakter polityczny, a konsekwencje niewłaściwego szacowania efektywności ochrony zdrowia mogą być poważne [Jacobs, Smith, Street, 2013, s. 208, 210]. B. Filipiak podkreśla, że to właśnie błędne decyzje wynikające $\mathrm{z}$ działań politycznych są istotnym czynnikiem zagrażającym płynności finansowej JST. Kluczowym wyznacznikiem zarządzania ryzykiem w finansach JST powinno być podjęcie działań zmierzających do zapewnienia bezpieczeństwa finansowego oraz ograniczenia strat nieuniknionych [Filipiak, 2011, s. 307, 316]. S. Golinowska i in. zwracają uwagę, że w Polsce nastapiło pewne rozmycie odpowiedzialności za finansowanie ochrony zdrowia pomiędzy JST, Narodowym Funduszem Zdrowia a rządem. Żaden z zewnętrznych organów nie czuje się w pełni odpowiedzialny za trudną sytuację SPZOZ, nikt nie dysponuje również dostatecznie skutecznymi instrumentami zaradczymi - ani właściciel, ani płatnik, ani kierownik SPZOZ [Golinowska i in., 2012, s. 62, 90, 120].

Abstrahując od powodów zaistniałego stanu rzeczy, poprawa sytuacji finansowej SPZOZ zwiększyłaby bezpieczeństwo finansów samorządowych. Według S. Golinowskiej przerwanie procesu zadłużania się SPZOZ wymaga przede wszystkim nowych regulacji dotyczących ich statusu oraz koordynacji polityki zdrowotnej państwa [Golinowska i in., 2012, s. 94].

\section{Literatura}

CSIOZ, 2017, Biuletyn Statystyczny Ministerstwa Zdrowia, Warszawa.

Dercz M., 2005, Samorzadony model systemu ochrony zdrowia, Instytut Spraw Publicznych, „Analizy i Opinie”, nr 43.

Dercz M., Izdebski H., 2001, Organizacja ochrony zdrowia w Rzecapospolitej Polskiej w świetle obowiazujacego ustawodawstwa, Polskie Wydawnictwo Prawnicze Iuris, Warszawa Poznań.

Filipiak B., 2011, Finanse samorzadowe. Nowe wyžmania bieżace i perspektywiczne, Difin, Warszawa.

Getzen T.E., 2000, Ekonomika zdrowia. Teoria i praktyka, PWN, Warszawa.

Golinowska S. (red.), 2008, Finansowanie ochrony zdrowia w Polsce. Raport Zielona Ksiega II.

Golinowska S. (red.), 2015, Od ekonomii do ekonomiki zdrowia, PWN, Warszawa.

Golinowska S., Sowada C., Tambor M., Dubas K., Jurkiewicz-Świetek I., Kocot E., Seweryn M., 2012, Równowaga finansowa oraz efektywnośc w polskim systemie ochrony zdrowia. Problemy $i$ myzwania, Uniwersyteckie Wydawnictwo Medyczne Vesalius, Kraków.

GUS, 2017, Zdrowie i ochrona ₹drowia w 2016 r., Warszawa.

Jacobs R., Smith P.C., Street A., 2013, Mierzenie efektywności w ochronie ₹drowia, Wolters Kluwer business, Warszawa.

Karski J. B., 2012, Polityka zdrowotna samorzadu terytorialnego, CeDeWu, Warszawa.

KRRIO, 2017, Sprawozdanie z działalności regionalnych ižb obrachunkonych $i$ wylkonania budìetu przez jednostki samorzadu terytorialnego w 2016 roku, Warszawa. 
McIntyre D., Kutzin J., 2016, Health financing country diagnostics: a foundation for national strategy development, WHO, Geneva.

MZiOS, 1998, Transformacja systemu ocbrony zdrowia w Polsce, Warszawa.

NIK, 2015, Driatalność sapitali samorzadowych przekesztatconych w spótki kapitatowe. Informacja o wynikach kontroli 196/2014/P/14/061/KZD, Warszawa.

Pietraszewska-Macheta A., Sidorko A., Kowalska-Mańkowska I., Urban K., Fryźlewicz-Chrapisińska E. (red.), 2018, Ustawa o swriadczeniach opieki zdrowotnej finansowanych ze środkón publicznych. Komentary, Wolters Kluwer, Warszawa.

RPWDL, https://rpwdl.csioz.gov.pl/RPM/Search [data wejścia: 21.02.2018].

Sprawozdania z.uykonania budżetu panstwa za 2014 r., 2015 r., 2016 r., Warszawa.

Suchecka J. (red.), 2015, Finansowanie ochrony zdrowia. Wybrane zagadnienia, Wolters Kluwer business, Warszawa.

Walshe K., Smith J. (red.), 2011, Zarzadzanie w opiece zdrowotnej, Wolters Kluwer business, Warszawa.

Włodarczyk C., Poździoch S., 2001, Systemy zdrowotne. Zarys problematyki, Wydawnictwo Uniwersytetu Jagiellońskiego, Kraków.

Wolska H., Gonet W., 2017, Konsekwencje wyboru formy organizacyjno-prawnej do wykeonywania zadania z zakeresu ochrony zdrowia przez samorzad terytorialny, [w:] Charakter i konstrukcja zadań samorz̨adu terytorialnego, Stec M., Płażek S. (red.), Wolters Kluwer, Warszawa.

Wydatki JST na ochrone zdrowia - Raport 2017, 2017, Pismo Samorządu Terytorialnego „Wspólnota”, Warszawa.

\section{Akty prawne}

Konstytucja Rzeczypospolitej Polskiej z dnia 2 kwietnia 1997 r., Dz.U. nr 78 poz. 483, z późn. zm.

Ustawa z dnia 15 kwietnia 2011 r. o działalności leczniczej, Dz.U. 2018 poz. 160.

Ustawa z dnia 27 sierpnia 2004 r. o świadczeniach opieki zdrowotnej finansowanych ze środków publicznych, Dz.U. 2017 poz. 1938 z późn. zm.

Ustawa z dnia 27 sierpnia 2009 r. o finansach publicznych, Dz.U. 2017 poz. 2077 z późn. zm.

Ustawa z dnia 28 lutego 2003 r. Prawo upadłościowe, Dz. U. 2017 poz. 2344 z późn. zm. 